\title{
The magmatic plumbing systems of the Campi Flegrei and Ischia volcanoes (Southern Italy) from chlorine constraints
}

HÉLÈNE BALCONE-BOISSARD ${ }^{1}$, GEORGES BOUDON ${ }^{2}$, GIOVANNI ORSI ${ }^{3}$, JAMES WEBSTER ${ }^{4}$, LUCIA CIVETTA ${ }^{3}$, MASSIMO D'ANTONIO ${ }^{5}$ AND GÉRALDINE ZDANOWICZ ${ }^{6}$

${ }^{1}$ Sorbonne Université - ISTeP

${ }^{2}$ Université de Paris, Institut de physique du globe de Paris, CNRS, F-75005

${ }^{3}$ INGV - Napoli

${ }^{4}$ Dept. of Earth \& Planetary Sciences AMNH

${ }^{5}$ Università degli Studi di Napoli Federico II

${ }^{6}$ IPGP

Presenting Author: helene.balcone_boissard@sorbonneuniversite.fr

Definition of the plumbing system geometry and the magma storage conditions prior to an eruption represent major goals in volcanology for their implications on the eruptive style and thus the management of future volcanic crises. Here $\mathrm{Cl}$ is used as a geobarometer for alkaline magmas in order to discuss the geometry of the Campi Flegrei volcanic complex. The results obtained on representative fallout deposits of selected explosive eruptions of Campi Flegrei evidence a shallow multidepth plumbing system. We describe evidence for a most-shallow reservoir located at a depth equivalent of $65 \mathrm{MPa}$ for Agnano Monte Spina eruptions $(4.67 \mathrm{ka})$. Conversely, for the Agnano Pomici Principali (12 ka) and the Astroni 6 (4.23 ka) eruption, the pressure is higher, $\sim 100 \mathrm{MPa}$, close to the $115 \mathrm{MPa}$ deduced for the last explosive eruption of Monte Nuovo (AD 1538). The pressure estimates for the two ignimbritic eruptions are discussed in detail with respect to magma withdrawal models published for these eruptions. The pressure domains of storage of the magma leading to the fallout phase of these two eruptions, as deduced from the $\mathrm{Cl}$ geobarometer, provides evidence for contrasted domains: a shallow one ( $40 \mathrm{MPa})$ associated to a deeper one ( $\sim 150 \mathrm{MPa})$ for the Campanian Ignimbrite eruption (39 ka) and a deeper one $(\sim 130-165 \mathrm{MPa})$ for the Neapolitan Yellow Tuff eruption (14.9 ka). For comparison, the reservoir leading to the Cretaio eruption of Ischia island (AD 430), the only studied eruption of Ischia, is located at the greatest pressure and depth, $140 \mathrm{MPa}$. Another interesting result is the influence of oxidized $\mathrm{S}$ on $\mathrm{Cl}$ solubility as highlighted by the difference between the Campanian Ignimbrite and the other eruptions: indeed, to correctly interpret the Campanian Ignimbrite in terms of pressure, no influence of $\mathrm{S}$ is noticed, contrary to the other eruptions, as the Neapolitan Yellow Tuff eruption. In addition, compared to Mount Somma - Vesuvius, the magma plumbing system of the Campi Flegrei volcanic complex is shallower, erupting more homogeneous differentiated magma. Such approach of the geometry of the plumbing system through $\mathrm{Cl}$ investigations may be applied to all alkali-rich magma systems. 